\title{
PENINGKATAN KEMAMPUAN MEMBACA CEPAT DENGAN METODE SQ3R PADA SISWA SD
}

\author{
Heppi Isti Nurani*, Raheni Suhita, dan Edy Suryanto \\ Program Studi Pendidikan Bahasa dan Sastra Indonesia FKIP Universitas Sebelas Maret
}

\begin{abstract}
This research aims at improving the quality of: (1) the process of teaching speed reading using $S Q 3 R$ method, and (2) the learning achievement of speed reading SQ3R method. This action research was conducted at the fifth class of a State Elementary School in Karang Duren. The data sources are events, participants, and documents. The data were collected by observation, interview, test, and questionnaire. The techniques used for validating data are source triangulation, method triangulation, and participants review. The data were analyzed using descriptive comparative analysis. The result shows that SQ3R method could improve quality of learning process and learning achievement of speed reading. The improvement of the quality of learning process could be reflected in the students' activeness in joining apperception, paying attention, in getting interest, and getting motivated. The students' thoroughness in learning also improved. The achievement quality improvement could be seen from the increase of percentage (i.e. $52.6 \%$ in cycle $1,68 \%$ in cycle 2 , and $84.2 \%$ in cycle 3 ).
\end{abstract}

Keywords: reading ability, $S Q 3 R$ method,speed reading

\begin{abstract}
Abstrak: Penelitian ini bertujuan meningkatkan kualitas: (1) proses pembelajaran membaca cepat dengan metode SQ3R dan (2) hasil pembelajaran membaca cepat dengan metode SQ3R. Penelitian tindakan kelas (PTK) ini dilaksanakan di kelas V SD Negeri I Karang Duren. Sumber data diperoleh dari tempat dan peristiwa, partisipan, dan dokumen. Pengumpulan data dilakukan dengan cara observasi, wawancara, tes, dan angket. Teknik validasi data menggunakan triangulasi sumber data, triangulasi metode, dan revieu partisipan. Data dianalisis dengan teknik analisis komparatif deskriptif. Hasil penelitian disimpulkan bahwa metode $S Q 3 R$ dapat meningkatkan kualitas proses dan kualitas pembelajaran membaca cepat. Peningkatan kualitas proses terefleksi dari keaktifan siswa dalam mengikuti apersepsi, perhatian, serta minat dan motivasi. Ketuntasan siswa dalam belajar juga mengalami peningkatan. Peningkatan kualitas hasil ditunjukkan perkembangan dari $52,6 \%$ pada siklus I menjadi $68 \%$ pada siklus II, dan $84,2 \%$ pada siklus III.
\end{abstract}

Kata kunci: kemampuan membaca, metode $S Q 3 R$, membaca cepat

Alamat korespondensi: Jalan Ir. Sutami 36 A. FKIP. Universitas Sebelas Maret. Surakarta.

e-mail: edikelik_uns@yahoo.co.id. 


\section{PENDAHULUAN}

Membaca cepat merupakan salah satu jenis kegiatan membaca yang diterapkan di SD. Ada sejumlah kompetensi dasar yang hendak dicapai dalam mata pelajaran bahasa Indonesia pada jenjang pendidikan tersebut. Pada Kurikulum Tingkat Satuan pendidikan (KTSP) mata pelajaran bahasa Indonesia kelas $\mathrm{V}$, kompetensi dasar membaca yang tercantum ialah membaca cepat 75 kata per menit. Berdasarkan keterangan di atas dapat disimpulkan bahwa siswa kelas V SD diharapkan mampu membaca sejumlah 75 kata dalam waktu satu menit dan siswa juga harus mampu memahami isi bacaan dengan menjawab pertanyaan dengan benar minimal 70\%. Jadi, ada dua kemampuan yang harus dimiliki siswa kelas V SD dalam membaca cepat, yaitu kemampuan dengan kecepatan kata per menit dan memahami isi bacaan minimal $70 \%$.

Kemampuan siswa kelas V SD Negeri I Karang Duren dalam membaca khususnya membaca cepat masih rendah. Berdasarkan wawancara dengan guru, bahwa selama ini kemampuan membaca cepat siswa belum dapat dicapai secara maksimal oleh siswa. Hal ini disebabkan oleh kemampuan membaca cepat siswa belum merata. Selain itu, siswa masih menggunakan kebiasaan buruk yang dapat menghambat kecepatan membaca siswa. Berdasarkan pengamatan yang dilakukan guru dalam pembelajaran membaca, 60\% lebih siswa dari 19 siswa membaca dengan teknik dan metode yang kurang efektif dan efisien. Hal ini ditandai sebagian besar siswa masih menggunakan kebiasaan buruk dalam membaca. Kebiasaan-kebiasaan itu, antara lain: membaca dengan vokalisasi sebanyak 78,9\%, menggerakan kepala sebanyak $73,68 \%$, bibir bergerak-gerak sebanyak $63,15 \%$, menunjuk dengan jari atau alat lain sebanyak 57,8\%, subvokalisasi (melafalkan apa yang dibacanya dalam hati atau pikiran) sebanyak $63,15 \%$, jarak mata terlalu dekat dengan teks sebanyak 73,68\%, dan sikap duduk tidak tegap sebanyak $68,42 \%$. Selain itu, siswa telihat kurang antusias dalam mengikuti proses pembelajaran.

Rendahnya kemampuan membaca cepat siswa disebabkan oleh faktor guru maupun siswa sendiri. Salah satu faktor penyebabnya rendahnya tingkat membaca cepat adalah metode 
yang digunakan oleh guru masih bersifat konvensional. Cara yang sering dilakukan untuk pembelajaran membaca cepat adalah siswa disuruh membaca dalam hati, kemudian menjawab pertanyaan yang berkaitan dengan bacaan yang diberikan. Guru belum pernah mengukur seberapa besar kecepatan membaca yang dimiliki oleh siswa serta seberapa besar persentase pemahaman isi yang dicapai siswanya, guru beranggapan bahwa yang penting setelah membaca, siswa dapat menjawab pertanyaan yang tersedia.

Upaya untuk menghilangkan kebiasaan buruk yang dapat menghambat kecepatan membaca dan untuk meningkatkan kemampuan membaca cepat adalah dengan menerapkan metode survei, question, read, recite, dan review $(S Q 3 R)$. Menurut Soedarso (2005: 59), sistem membaca $S Q 3 R$ dipopulerkan oleh Francis P. Robinson pada tahun 1941. Metode SQ3R merupakan sistem membaca yang populer digunakan oleh orang, yang terdiri dari lima langkah, yaitu: survei, question, read, recite, dan revieu.Hal senada juga dikemukakan oleh Sudarno, dkk. (2004: 132), metode $S Q 3 R$ adalah suatu metode membaca untuk menemukan ide-ide pokok dan pendukungnya, serta untuk membantu mengingat agar lebih tahan lama melalui lima langkah kegiatan yaitu: survei, question, recite, read, dan revieu. Penerapaan metode SQ3R diawali dengan siswa membangun gambaran secara umum tentang bahan yang akan atau sedang dipelajari, lalu siswa membuat pertanyaan dari judul atau subjudul suatu bab, dilanjutkan dengan membaca untuk mencari jawaban dari pertanyaan tersebut.

Salah satu kelebihan dari metode $S Q 3 R$ adalah dengan metode ini siswa cenderung lebih mudah menguasai isi bacaan (Soedarso, 2005:59). Hal ini terjadi karena sebelum membaca, pembaca melakukan survei bacaan terlebih dahulu untuk mendapatkan gagasan umum apa yang akan dibaca. Kemudian ia mengajukan berbagai pertanyaan pada diri sendiri yang jawabannya terdapat dalam bacaan tersebut. Lebih lanjut, Santosa (dalam Yasrulefendi, 2008), keunggulan metode $S Q 3 R$ dapat digunakan untuk membaca bacaan menggunakan bahasa yang sama dengan bahasa yang digunakan oleh pembaca.

Berdasarkan latar belakang tersebut, peneliti memberikan alternatif pemecahan masalah kepada guru, yakni 
dengan menerapkan metode $S Q 3 R$ sebagai sarana untuk meningkatkan kemampuan membaca cepat pada siswa kelas V SD Negeri I Karang Duren. Dengan metode ini diharapkan dapat menumbuhkan minat dan keaktifan siswa dalam pembelajaran membaca, khususnya membaca cepat. Di samping itu, diharapkan dapat menghilangkan kebiasaan buruk dalam membaca cepat.

\section{METODE PENELITIAN}

Penelitian ini dilakukan di SD Negeri I Karang Duren. Kelas yang digunakan untuk pelaksanaan penelitian adalah kelas $\mathrm{V}$ yang berjumlah 20 siswa. Ruang kelas V terletak di sebelah berat. Ukuran ruang kelas $\mathrm{V}$ adalah $7 \mathrm{x}$ 7 m.Penelitian ini dilakukan selama 6 bulan, yakni mulai Januari 2011 sampai dengan Juni 2011. Adapun yang menjadi subjek penelitian adalah siswa kelas VSD Negeri I Karang Duren yang berjumlah 19 siswa, yang terdiri dari siswa laki-laki berjumlah 13 dan siswa perempuan berjumlah 6 .

Penelitian ini berbentuk penelitian tindakan kelas (Classroom Action Research), yaitu penelitian yang merupakan hasil kolaborasi antara peneliti dan guru sehingga dapat meningkatkan kualitas pembelajaran.
Suharsimi Arikunto, Suhardjono \& Supardi (2006: 58) mengemukakan bahwa penelitian tindakan kelas merupakan suatu penelitian tindakan yang dilakukan dengan tujuan untuk memperbaiki mutu praktik pembelajaran di kelas.Dalam penelitian ini menggunakan tiga sumber data, yaitu: informan, dokumen dan arsip, dan tempat dan peristiwa.Teknik pengumpulan data yang digunakan adalah observasi, wawancara, tes, dan angket.

Teknik-teknik yang digunakan untuk memeriksa keabsahan data adalah sebagai berikut: Triangulasi sumber data, Triangulasi metode, Revieu informan, dan Triangulasi teori.Teknik analisis data menggunakan analisis deskriptif komparatif hasil tes membaca antarsiklus, yaitu dengan cara membandingkan nilai tes antarsiklus dengan indikator kerja yang telah ditetapkan.Indikator yang ingin dicapai dalam penelitian ini adalah meningkatnya kualitas proses dan hasil belajar dalam pembelajaran membaca cepat. Proses pembelajaran dikatakan berhasil bila setidaknya $70 \%$ siswa terlibat secara aktif, baik fisik, mental, sosial selama proses pembelajaran.Siswa dikatakan berhasil 
(tuntas) dalam membaca cepat jika mendapatkan nilai $\geq 65$ dan siswa yang mendapatkan nilai di bawah 65 dinyatakan belum tuntas (KKM yang ditetapkan adalah $\geq 65$ ).

\section{Rancangan Siklus I}

1. Merencanakan Tindakan Siklus I

Tahap perencanaan tindakan meliputi.

a. Membuat skenario pembelajaran. Adapun skenario pembelajarannya, sebagai berikut: (1) Guru melakukan apersepsi,(2) Guru menjelaskan tujuan pembelajaran yang hendak dicapai pada pertemuan hari ini, (3)Guru menggali pengalaman siswa berkaitan dengan materi membaca cepat, (4) Guru mengarahkan pemahaman siswa tentang membaca cepat, (5) Guru bertanya jawab dengan siswa tentang pengertian dan tujuan dalam membaca cepat, (6) Guru menjelaskan tentang pengertian dan tujuan dalam membaca cepat, (7) Guru menjelaskan rumus untuk menghitung kecepatan baca dan KEM, (8) Guru membagikan teks bacaan yang berjudul "Kelik Kagumi Sri Sultan HB X", (9) Siswa membaca teks tersebut secara cepat untuk mengetahui gambaran secara umum tentang teks tersebut (survei), dengan waktu yang telah ditentukan, (10)Siswa membuat pertanyaan tentang teks tersebut (question), (11)Siswa membaca teks tersebut secara teliti (read), (12) Siswa menjawab pertanyaan yang telah dibuatnya berdasarkan pemahaman yang telah dibaca (recite), (13) Siswa membuat rangkuman tentang teks tersebut (revieu), (14) Guru mengambil teks tersebut, (15) Siswa mengerjakan soal tentang teks tersebut secara individu, (16) Siswa menghitung waktu berlangsungnya kegiatan membaca secara individu, (17) Siswa menghitung jumlah kata yang telah dibaca secara individu, (18) Siswa menghitung kecepatan membacanya dengan rumus yang telah disampaikan oleh guru, dan (19) Guru bersama siswa melakukan refleksi terhadap pembelajaran yang telah dilakukan dan memberikan rewardkepada siswa dengan hasil pekerjaan terbaik. Setelah itu semua siswa diminta untuk bertepuk tangan dan agar 
termotivasi mengerjakan tugas berikutnya.

b. Mempersiapkan

sarana pembelajaran

c. Mempersiapkan instrumen penelitian

d. Mengajukan solusi alternatif berupa penerapan metode $S Q 3 R$ dalam pembelajaran membaca cepat.

2. Melaksanakan Perencanaan Siklus I Tahap ini dilakukan dengan melaksanakan skenario pembelajaran yang telah direncanakan. Dalam satu siklus, ada 2 kali pertemuan dengan alokasi waktu 2 × 35 menit. Pada tahap ini juga dilakukan kegiatan observasi terhadap dampak dari tindakan yang dilakukan. Selain itu, pengamatan di-lakukan untuk mengumpulkan data yang nantinya diolah untuk menentukan tindakan yang akan dilakukan selanjutnya.

\section{Observasi}

Observasi dilakukan peneliti saat pembelajaran membaca cepat berlangsung. Observasi berupa kegiatan pemantauan, pencatatan, serta pendokumentasian segala kegiatan selama pelaksanaan pembelajaran membaca cepat berlang- sung. Peneliti mengamati dan menilai keaktifan siswa dari apersepsi sampai akhir pembelajaran membaca cepat. Peneliti juga mengamati aktivitas guru selama pembelajaran. Adapun kegiatan guru adalah menilai kemampuan membaca cepat dengan mengisi rubrik penilaian yang telah disediakan. Data yang diperoleh dari observasi kemudian diinterpretasi guna mengetahui kelebihan dan kekurangan dari tindakan yang dilakukan.

\section{Analisis dan Refleksi}

Pada tahap ini, peneliti menganalisis data yang telah terkumpul dari hasil observasi, dan interpretasi sehingga diperoleh kesimpulan bagian yang perlu diperbaiki dan bagian mana yang sudah mencapai tujuan pembelajaran. Dalam melakukan refleksi, peneliti bekerjasama dengan guru sebagai kolaborator. Selain itu, peneliti dengan gur mengadakan diskusi untuk menentukan langkah-langkah perbaikan (solusi pemecahan masalah yang dihadapi dalam pelaksanaan yang telah dilakukan). Setelah itu, ditarik kesimpulan terhadap penelitian yang telah 
dilakukan berhasil atau tidak, sehingga berdasarkan kesimpulan tersebut peneliti dan guru menentukan langkah selanjutnya.

\section{RancanganSiklus II dan III}

Pada siklus II dilakukan dengan tahapan-tahapan seperti siklus I tetapi didahului dengan perencanaan ulang berdasarkan hasil-hasil yang diperoleh pada siklus I (refleksi), sehingga kelemahan yang terjadi pada siklus I tidak terjadi pada siklus II. Demikian halnya pada siklus III dan seterusnya, termasuk perwujudan tahap pelaksanaan, observasi dan interpretasi, serta analisis dan refleksi yang mengacu pada tindakan sebelumnya.

\section{HASIL DAN PEMBAHASAN}

\section{Siklus I}

Pada siklus I, siswa yang mencapai kompetensi penilaian proses hanya 8 siswa atau $47 \%$ dari jumlah keseluruhan siswa, dengan nilai terendah 57,0 dan nilai tertinggi 80.Nilai rata-rata yang dicapai untuk penilaian proses adalah 61,26 . Penilaian hasil menunjukkan siswa yang mencapai kompetensi sebanyak 6 siswa atau $32 \%$ dari jumlah keseluruhan siswa dengan nilai terendah 30 dan nilai tertinggi 70 , dan nilai rata-rata yang dicapai adalah 51,57. Terjadinya penurunan kebiasaan buruk membaca siswa, antara lain: vokalisasi sebanyak $68,4 \%$, subvokalisasi sebanyak 57,8\%, membaca dengan menggerakan bibir sebanyak 52,6\%, menggerakan kepala sebanyak 63,1\%, membaca dengan menunjuk benda sebanyak 52,6\%, jarak mata terlalu dekat dengan teks sebanyak $63,1 \%$, dan sikap badan (tidak tegap) sebanyak $57,8 \%$.

\section{Siklus II}

Pada siklus II, siswa yang mencapai kompetensi penilaian proses hanya 10 siswa atau $53 \%$ dari jumlah keseluruhan siswa, dengan nilai terendah 60 dan nilai tertinggi 87 . Nilai rata-rata yang dicapai untuk penilaian proses adalah 62,1. Penilaian hasil menunjukkan siswa yang mencapai kompetensi sebanyak 13 siswa atau $68 \%$ dari jumlah keseluruhan siswa dengan nilai terendah 40 dan nilai tertinggi 80. Nilai rata-rata yang dicapai adalah 61,5 .Terjadinya penurunan kebiasaan buruk membaca siswa, antara lain: vokalisasi sebanyak 47,36\%, subvokalisasi sebanyak 52,63\%, membaca dengan menggerakan bibir sebanyak 47,36\%, menggerakan kepala 
sebanyak 57,8\%, membaca dengan menunjuk benda sebanyak 36,84\%, jarak mata terlalu dekat dengan teks sebanyak 52,63\%, dan sikap badan (tidak tegap) sebanyak 47,36\%.

\section{Siklus III}

Pada siklus III siswa yang mencapai kompetensi pada penilaian proses mencapai 16 siswa atau 84,2\% dari jumlah keseluruhan siswa, dengan nilai terendah 67 dan nilai tertinggi 87. Rata-rata nilai kelas yang diperoleh siswa mencapai 74,2. Penilaian hasil menunjukkan 16 siswa mencapai kompetensi yang ditetapkan atau $84,2 \%$ dari keseluruhan jumlah siswa dengan nilai terendah 50 dan nilai tertinggi 90.Nilai rata-rata kelas yang diperoleh siswa mencapai 72,1. Terjadinya penurunan kebiasaan buruk membaca siswa, antara lain: vokalisasi sebanyak $31,57 \%$, subvokalisasi sebanyak $42,10 \%$, membaca dengan menggerakan bibir sebanyak 36,84\%, menggerakan kepala sebanyak 26,31\%, membaca dengan menunjuk benda sebanyak $31,57 \%$, jarak mata terlalu dekat dengan teks sebanyak $36,84 \%$, dan sikap badan (tidak tegap) sebanyak 31,57\%.

Berdasarkan hasil pengamatan terhadap tindakan yang dilakukan pada siklus I sampai siklus III dapat dinya- takan bahwa terjadinya peningkatan kualitas pembelajaran, baik pada proses maupun hasil kemampuan membaca cepat dengan penerapan metode $S Q 3 R$. Penilaian proses, dapat dilihat dari sikap siswa ketika mengikuti kegiatan pembelajaran. Sikap bermula dari perasaan suka atau tidak suka yang terkait dengan kecenderungan seseorang dalam merespons sesuatu/objek. Sikap juga merupakan ekspresi dari nilai-nilai atau pandangan hidup yang dimiliki seseorang. Sikap dapat dibentuk sehingga terjadi perilaku atau tindakan yang diingikan.

Ditambahkan pula oleh Suwandi (2010: 80-81) bahwa secara umum objek/sikap yang perlu dinilai dalam proses pembelajaran meliputi beberapa hal, yakni sikap terhadap materi pelajaran (motivasi mengikuti pelajaran, keseriusan, semangat); sikap terhadap guru/pengajar (interaksi, respons); dan sikap terhadap proses pembelajaran (perhatian, kerja sama, konsentrasi, dsb) sedangkan penilaian hasil, Sujana (2008: 3) mengungkapkan bahwa penilaian hasil belajar adalah proses pemberian nilai terhadap hasil-hasil belajar yang dicapai oleh siswa dengan kriteria tertentu. Hal ini mengisyaratkan bahwa objek yang dinilai adalah hasil 
belajar siswa yang disesuaikan dengan tujuan pembelajaran. Dengan demikian, penelitian ini telah berhasil menjawab rumusan masalah yang dikemukakan peneliti.

Metode $S Q 3 R$ merupakan sistem membaca yang populer digunakan oleh orang, yang terdiri dari lima langkah, yaitu: survei, question, read, recite, dan revieu (Soedarso, 2005: 59).Penerapaan metode $S Q 3 R$ diawali dengan siswa membangun gambaran secara umum tentang bahan yang akan atau sedang dipelajari, lalu siswa membuat pertanyaan dari judul atau subjudul suatu bab, dilanjutkan dengan membaca untuk mencari jawaban dari pertanyaan tersebut.

Hasil penelitian yang dicapai dengan siklus I sampai siklus III membuktikan bahwa metode $S Q 3 R$ cukup membantu dalam peningkatan kualitas pembelajaran membaca cepat pada siswa kelas V SD Negeri I Karang Duren. Peningkatan kualitas pembelajaran membaca cepat dapat dilihat dari dua hal, yaitu Peningkatan Kualitas Proses dan peningkatan kualitas hasil . pertama ,peningkatan kualitas proses pembelajaran dapat dilihat dari beberapa indikator, yaitu: (a) Siswa lebih aktif saat mengikuti pembelajaran, dari siklus I hingga siklus III mengalami peningkatan. Hal ini dapat dilihat dari persentase keaktifan siswa antarsiklus, yaitu $37 \%$ atau sebanyak 7 siswa (siklus I) menjadi sekitar $47,36 \%$ atau sebanyak 9 siswa (pada siklus II) dan mencapai $78,9 \%$ atau sebanyak 15 siswa (pada siklus III), (b) Siswa terlihat lebih aktif dan perhatian saat mengikuti pembelajaran, peningkatan keaktifan siswa selama mengikuti kegiatan pembelajaran pada siklus I hanya $37 \%$ atau sebanyak 7 siswa, siklus II sekitar 47,32\% atau sebanyak 9 siswa, dan siklus III menjadi $74 \%$ atau sebanyak 14 siswa, dan (c) Minat dan motivasi siswa dalam mengikuti pembelajaran membaca cepat. Pemilihan metode harus sesuai dan dipertimbangkan oleh guru dengan penyesuaian terhadap isi, kondisi siswa, dan pembelajaran apa yang disampaikan. Pertimbangan pokok dalam menentukan metode pembelajaran adalah keefektifan proses belajar yang berorientasi pada siswa (Sumiati dan Asra, 2008: 12). Pada siklus I siswa yang tampak berminat dan memiliki motivasi saat mengikuti pembelajaran sekitar $32 \%$ dan pada siklus II meningkat menjadi $47 \%$. Pada siklus terakhir terjadi peningkatan yang cukup 
signifikan yakni sebesar $74 \%$ atau sebanyak 14 siswa tampak berminat serta termotivasi pada pembelajaran membaca cepat.

Peningkatan kualitas proses juga tampak dari peningkatan nilai proses siswa. Pada tahap pratindakan, siswa yang mencapai kompetensi pada penilaian proses hanya 4 siswa atau sekitar $21 \%$ dari jumlah keseluruhan siswadengan nilai terendah 40,0 dan nilai tertinggi 67. Pada siklus I, siswa yang mencapai kompetensi penilaian proses hanya 8 siswa atau $47 \%$ dari jumlah keseluruhan siswa, dengan nilai terendah 57,0 dan nilai tertinggi 73 . Pa- da siklus II, siswa yang mencapai kompetensi pada penilaian proses hanya 10 siswa atau 53\% dari jumlah keseluruhan siswa, dengan nilai terendah 60 dan nilai tertinggi 87.Pada siklus III, siswa yang mencapai kompetensi pada penilaian proses hanya 16 siswa atau $84,2 \%$ dari jumlah keseluruhan siswa, dengan nilai terendah 67 dan nilai tertinggi 87 . Peningkatan penilaian proses pembelajaran membaca cepat dari pratindakan sampai siklus III dapat dilihat pada Tabel 1 berikut ini.

Tabel 1. Peningkatan Penilaian Proses Pembelajaran Membaca Cepat Dari Pratindakan Sampai Siklus III.

\begin{tabular}{ccccc}
\hline Siklus & $\begin{array}{c}\text { Nilai Ter- } \\
\text { endah }\end{array}$ & Nilai Tertinggi & Tuntas & Frekuensi Relatif \\
\hline Pratindakan & 40 & 67 & 4 & $4 / 19 \times 100 \%=21 \%$ \\
I & 57 & 73 & 8 & $8 / 19 \times 100 \%=47 \%$ \\
II & 60 & 87 & 10 & $10 / 19 \times 100 \%=53 \%$ \\
III & 67 & 87 & 16 & $16 / 19 \times 100 \%=84,2 \%$ \\
\hline
\end{tabular}

Rata-rata nilai kelas yang diperoleh siswa juga mengalami peningkatan. Penilaian proses mengalami peningkatan dari 56 menjadi 61,26 kemudian meningkat menjadi 62,1 dan meningkat menjadi 74,2. Peningkatan nilai proses dalam pembelajaran membaca cepat ini dapat dilihat dalam Gambar 1 berikut ini.

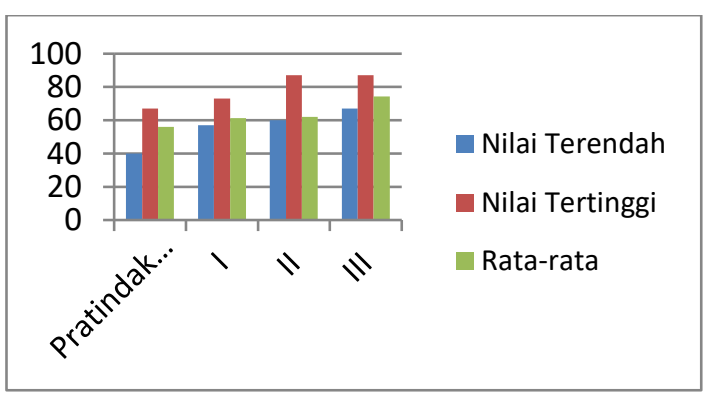

Gambar 1. Grafik Peningkatan Hasil Penilaian Proses Pembelajaran Membaca Cepat Siswa Kelas V SD Negeri I Karang Duren. 


$\begin{array}{lll}\text { Kedua } & \text { Peningkatan hasil } & \text { kompetensi sebanyak } 13 \text { siswa atau } \\ \text { pembelajaran terbukti dengan } & \text { sekitar } 68 \% \text { dengan nilai terendah } \\ \text { peningkatan nilai hasil membaca } & 50 \text { dan nilai tertinggi 80. Pada siklus } \\ \text { cepat siswa dari siklus I sampai } & \text { III, penilaian hasil menunjukkan } \\ \text { siklus III. Pada siklus I, penilaian } & \text { siswa yang mencapai kompetensi } \\ \text { hasil menunjukkan siswa yang } & \text { sebanyak 16 siswa atau } 84,2 \% \text { dari } \\ \text { mencapai kompetensi sebanyak } 6 & \text { jumlah keseluruhan siswa dengan } \\ \text { siswa atau sekitar 32\% dari jumlah } & \text { nilai terendah } 50 \text { dan nilai tertinggi } \\ \text { keseluruhan siswa dengan nilai } & 90 . \text { Peningkatan nilai pembelajaran } \\ \text { terendah } 30 \text { dan nilai tertinggi 70. } & \text { membaca cepat dari pratindakan } \\ \text { Pada siklus II, penilaian hasil } & \text { sampai siklus III dapat dilihat pada } \\ \text { menunjukkan siswa yang mencapai } & \text { Tabel } 2 & \text { berikut ini. }\end{array}$

Tabel 2. Peningkatan Nilai Pembelajaran Membaca Cepat Dari Siklus I Sampai Siklus

III.

\begin{tabular}{ccccc}
\hline Siklus & Nilai Terendah & Nilai Tertinggi & Tuntas & Frekuensi Relatif \\
\hline I & 30 & 70 & 10 & $10 / 19 \times 100 \%=52,6 \%$ \\
II & 50 & 80 & 13 & $13 / 19 \times 100 \%=68 \%$ \\
III & 50 & 90 & 16 & $16 / 19 \times 100 \%=84,2 \%$ \\
\hline
\end{tabular}

Rata-rata nilai kelas yang diperoleh siswa juga mengalami peningkatan. Nilai rata-rata siswa mengalami peningkatan yang cukup signifikan dari 51,5 kemudian meningkat menjadi 62,1 dan meningkat menjadi 72,1 pada siklus yang terakhir, dan terjadiinya penurunan kebiasaan membaca cepat dari pratindakan sampai siklus III. Peningkatan nilai hasil dalam pembelajaran membaca cepat ini dapat dilihat pada Gambar 2 berikut ini.

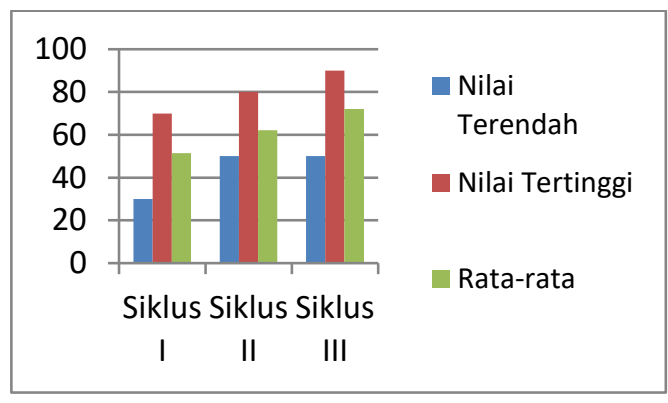

Gambar 2. Grafik Peningkatan Hasil Penilaian Pembelajaran Membaca Cepat Siswa Kelas V SD Negeri I Karang Duren.

Dengan menerapkan metode SQ3Rdalam pembelajaran membaca cepat, kemampuan membaca cepat mengalami peningkatan yang 
dinyatakan dengan semakin banyaknya siswa yang telah mendapatkan nilai ketuntasan belajar. Menurut Syah (dalam Masykur, dan Handayani 2006: 5), mengemukakan bahwa penerapan metode $S Q 3 R$ dapat meningkatkan hasil belajar karena metode ini memiliki keunggulan, antara lain: (1) metode $S Q 3 R$ mempunyai langkah-langkah yang yang jelas sehingga memudahkan siswa memahami teks materi, (2) menuntut siswa menjadi pebelajar yang aktif dan dan terarah langsung pada intisari yang ada dalam pokok materi, (3) menjadikan siswa dapat memahami dan mengingat materi dalam jangka waktu yang lebih lama,(4) dapat meningkatkan keaktifan dan keterlibatan siswa selama kegiatan pembelajaran berlangsung. Berdasarkan pemaparan di atas tampak bahwa penerapan metode $S Q 3 R$ dalam pembelajaran membaca cepat pada siswa kelas V SD Negeri I Karang Duren dapat meningkatkan proses dan hasil belajar siswa.

\section{KESIMPULAN}

Dari hasil penelitian dan pembahasan dapat disimpulkan bahwapenerapan metode $S Q 3 R$ dapat meningkatkan kualitas proses dan hasil pembelajaran membaca cepat pada siswa kelas
V SD Negeri I Karang Duren. Hal ini terbukti dengan adanya peningkatan dari pratindakan sampai siklus III. Pada siklus I, ketuntasan belajar sebanyak 6 siswa atau sekitar $32 \%$ dengan nilai terendah 30 dan nilai tertinggi 70 . Pada siklus II, penilaian hasil menunjukkan siswa yang mencapai kompetensi sebanyak 13 siswa atau sekitar 68\% dengan nilai terendah 50 dan nilai tertinggi 80. Pada siklus III, penilaian hasil menunjukkan siswa yang mencapai kompetensi sebanyak 16 siswa atau $84,2 \%$ dari jumlah keseluruhan siswa dengan nilai terendah 50 dan nilai tertinggi 90. Rata-rata nilai kelas yang diperoleh siswa juga mengalami peningkatan. Nilai rata-rata siswa mengalami peningkatan yang cukup signifikan dari 47,5 menjadi 51,57 kemudian meningkat menjadi 61,5 dan meningkat menjadi 72,1 pada siklus yang terakhir.

Selain itu, peningkatan proses dari pratindakan sampai siklus III juga mengalami peningkatan. Hali ini terbukti dengan indicator-indikator yang telah ditetapkan. Pada siklus I keaktifan siswa saat mengikuti apersepsi sebesar $37 \%$, pada siklus II sebesar $47,36 \%$, dan pada siklus III meningkat menjadi $78,9 \%$. Pada siklus I, siswa yang aktif 
mengikuti pembelajaran sebesar $37 \%$.

Pada siklus-siklus berikutnya keaktifan siswa selama mengikuti pembelajaran mengalami peningkatan yang signifikan. Peningkatan tersebut sebesar $47 \%$ pada siklus II dan $74 \%$ pada siklus III.
Pada siklus I siswa yang tampak berminat dan termotivasi sebanyak $32 \%$, pada siklus berikutnya terus mengalami peningkatan menjadi $47 \%$ pada siklus II dan $74 \%$ pada siklus III.

\section{DAFTAR PUSTAKA}

Arikunto, Suharsimi, Suhardjono, dan Supardi. (2006). Penelitian Tindakan Kelas. Jakarta: Bumi Aksara.

Masykur, Siti Khanafiyah, dan Handayani, Langlang. (2006). "Penerapan Metode SQ3R dalam Pembelajaran Kooperatif untuk Meningkatkan Hasil Belajar Fisika Pokok Bahasan Tata Surya Pada Siswa Kelas VII SMP”. Jurnal Pendidikan Fisika Indonesia, Volume (4) No.2 Juli 2006, halaman 1-6.

Soedarso. 2005. Speed Reading: Sistem Membaca Cepat dan Efektif. Jakarta: Gramedia Pustaka Utama.

Sudarno, Sugiyanto, dan Sukamto. (2004). "Metode Membaca SQ3R dan Pemanfaatan Sumber Belajar Pengaruhnya terhadap Kreativitas Siswa." Jurnal Teknologi Pendidikan. Volume (2) No. 03 Maret 2004, halaman 128-145

Sujana, Nana. (2008). Penilaian Hasil Proses Belajar Mengajar. Bandung: Remaja Rosdakarya.

Sumiati dan Asra. (2008). Metode Pembelajaran. Bandung: Wacana Prima.

Suwandi, Sarwiji (2010). Model Assesmen dalam Pembelajaran. Surakarta: UNS Press.

Yasrul efendi. (2008). "Peningkatan Kemampuan Membaca Cepat dengan Menggunakan Metode Speed Reading", dalam http://id.forums.word-press.com/to-pic-/peningkatan-kemampuan-membaca-cepat-dengan-menggunakan-metode-speed-reading,diunduh tanggal 15 Mei 2011. 